\title{
Response of Sorghum (Sorghum Bicolor L. Moench) To Potassium, Zinc, and Boron Fertilizers in Wag- Lasta, Northern, Ethiopia
}

Tilahun Esubalew ( $\square$ tilahun1215@gmail.com )

Sekota Dryland Agricultural Research Center

Workat Sebnie

Sekota Dryland Agricultural Research Center

\section{Research}

Keywords: Boron, Grain yield, Potassium, Sorghum, Zinc

Posted Date: December 16th, 2021

DOI: https://doi.org/10.21203/rs.3.rs-1102589/v1

License: (c) (i) This work is licensed under a Creative Commons Attribution 4.0 International License.

Read Full License 


\section{Abstract \\ Background}

In Ethiopia using fertilizer started in the early 1960. But it still depended solely on urea and DAP. Today, according to ATA and Ministry of Agriculture and Natural Resources $K, Z n, B, S$, and Cu are in deficit in Ethiopia and Amhara Region as well as in Wag-Lasta areas. But some studies conducted in Wag-Lasta and throughout the region in different crops indicate that these nutrients had no response on crop yields. So, this experiment was conducted in 2017 rain feed cropping season on five farmers' parcels per location to verify the response of sorghum to potassium, zinc, and boron fertilizers.

\section{Methods}

The treatments were: NPS, NPSK, NPSZnB, and NPSZnBK, with the recommended rate of 46 and $23 \mathrm{~kg}$ ha

${ }^{-1} \mathrm{~N}$ and $\mathrm{P}_{2} \mathrm{O}_{5}$ respectively for Sekota, $23 \mathrm{~kg} \mathrm{ha}^{-1} \mathrm{~N}$, and $\mathrm{P}_{2} \mathrm{O}_{5}$ for Lasta. Moreover, 150, 1.47, and $0.07 \mathrm{~kg}$ $h \mathrm{a}^{-1} \mathrm{KCl}, \mathrm{Zn}$, and $\mathrm{B}$ respectively used uniformly for both locations. The experiment was laid out in randomized complete block design (RCBD) with three replications. The collected data were analyzed by SAS software version 9.0.

\section{Results}

Analysis of variance revealed that the application of potassium, zinc, and boron had no significant effect ( $P \leq 0.05)$ on sorghum yield and yield components at all sites. The exchangeable potassium content in the soil of the study sites is high and very high. The result disagrees with the soil fertility map which showed more than $98 \%$ of potassium deficiency and more than $80 \%$ NPSZnB deficiency. Hence, the application of $K, Z n$, and $B$ fertilizers had no yield advantage over the recommended $N$ and $P$ fertilizers in the Wag-Lasta areas.

\section{Conclusions}

Therefore, currently to increase production and productivity of crops in Wag-Lasta areas using of recommended rate of nitrogen and phosphorous with organic fertilizer sources for each district is the best option rather than using $K, Z n$, and $B$ fertilizers.

\section{Background}

Agriculture is the master king of Ethiopia's economy, accounting for $34 \%$ of GDP and $85 \%$ of employment (Baye, 2017). However, the sector is not effective due to low soil fertility and inappropriate nutrient management practice. Sorghum (Sorghum bicolor (L.) Moench) is a viable food grain for many of the 
World's most food-insecure people who live in marginal areas with poor and erratic rains and poor soils (Onyango et al., 1998). In Ethiopia, sorghum is a major staple food crop, ranking second after maize in total production. It ranks third after wheat and maize in productivity per hectare, and after teff and maize in area cultivated. It is grown in almost all regions of Ethiopia, In Sekota and Lasta districts the crop is dominant. Sorghum production and productivity have been far below the potential. Currently, the average regional productivity is $2448 \mathrm{~kg} \mathrm{ha}^{-1}$, but, in the Waghimera zone, it was $1520 \mathrm{~kg} \mathrm{ha}^{-1}$, (CSA, 2017). The reasons were poor soil fertility, moisture stress, and inappropriate inorganic fertilizer rate (Amelework et al., 2016; Sebnie and Mengesha, 2018).

In Ethiopia, fertilizer use had been started since the early 1960s (Murphy, 1968). In the past three decades, Ethiopian agriculture depended solely on imported fertilizer products of urea and di-ammonium phosphate (DAP), sources of $\mathrm{N}$ and P. Today, according to the Agricultural Transformation Agency (ATA) and ministry of agriculture and natural resources (2016), soil fertility inventory conducted in some woredas of the country and the region from 2012-13 not only N, and P but also K, S, B, Cu, and Zn deficiencies are widespread. The fertility map of Wag-Lasta indicates that nearly $80 \%$ NPSZnB, $47 \%$ NPSB, and $98 \% \mathrm{~K}$ were deficit in the area. But the result of diagnostic nutrient omission trial conducted in Dehana and Lasta districts on wheat and teff and the validation studies on new fertilizers across the region for different crops indicated that potassium and new fertilizers did not affect the yields of the studied crops, (SDARC, unpublished; Amare et al., 2010; Amare et al., 2018).

Potassium, zinc, and boron nutrients are required and indispensable for crop optimum growth, development, and production (Hasanuzzaman et al., 2018), however, in Wag-Lasta these nutrients had no significant effect on crop yield due to the areas' soil had a high amount of exchangeable potassium amount. But the extension agent widely distributes NPSB, SPSZnB fertilizers to the farmers, which expose users to extra cost. Therefore, the study was conducted to verify the response of sorghum to potassium, zinc, and boron fertilizers application and to validate the soil fertility map developed by the Ethiopian soil information system (EthioSIS).

\section{Materials And Methods}

\section{Description of the study area}

The research was conducted in 2017 rain feed cropping season in Sekota and Lasta districts in 8 kebeles at 8 farmers' fields, found in Amhara National Regional State, Ethiopia. The sites located $12^{0} 43^{\prime} 38^{\prime \prime} \mathrm{N}$ longitudinal and $39^{\circ} 01^{\prime} 08^{\prime \prime} \mathrm{E}$ latitude with the altitude of 1915 meter, $12^{\circ} 43^{\prime} 52.82^{\prime \prime} \mathrm{N}$ Longitude and $39^{\circ}$ $01^{\prime 2} 22.01$ "E with an altitude of 1915 for Sekota district, $11^{\circ} 58^{\prime} 50.15^{\prime \prime} \mathrm{N}$ Longitude and $38^{\circ} 59^{\prime}$ '03.22"E latitude with the altitude of 1966 meters above sea level respectively. The district is semi-arid and the undulating land feature has a unimodal rainfall distribution system occurring in June, July, and August. The mean annual rainfall was 673.7 and $818.1 \mathrm{~mm}$, with maximum and the minimum average temperature of $27.22^{\circ} \mathrm{C}, 12.77^{\circ} \mathrm{C}$ and $24.7{ }^{\circ} \mathrm{C}, 13.6^{\circ} \mathrm{C}$ for Sekota and Lalibela respectively. 
In Wag-Lasta areas crop-livestock mixed farming system is dominantly practiced. The major grown crops are wheat (Triticum aestivum L.), sorghum (Sorghum bicolor L.), teff (Eragrostis teff (Zucc) Trotter), barley (Hordeum vulgar $L$ ), and faba bean (Vicia faba L.). The livestock productions are beekeeping, cattle, sheep, goat, donkey, and poultry. Soil types are: - calcic Xero, cambic Arenosols, chromic Cambisols, eutric Cambisols, eutric Regosols, Leptosols and Orthic solonchaks. Among them Eutric Cambisols are the dominant for Sekota. In Lasta district also eutric Cambisols, eutric Regosols, Leptosols and vertic Cambisols among them Eutric Cambisols and Vertic Cambisols cover most part of Lasta.

\section{Experimental design and treatments}

The treatments were NPS, NPSK, NPSZnB, and NPSZnBK. N and P fertilizers amount adjusted by the recommendation rate of 46 and $23 \mathrm{~kg} \mathrm{ha}^{-1} \mathrm{~N}$ and $\mathrm{P}_{2} \mathrm{O}_{5}$ for Sekota respectively, and $23 \mathrm{~kg} \mathrm{ha}^{-1}$ for both N and $\mathrm{P}_{2} \mathrm{O}_{5}$ for Lasta district, murite potash applied by blanket recommendation of $150 \mathrm{~kg} \mathrm{ha}^{-1} \mathrm{KCl}, \mathrm{Zn}$, and $B$ uniformly applied 0.7 and $1.47 \mathrm{~kg} \mathrm{ha}^{-1}$ for all trial sites respectively. NPS, NPSZnB, and murite potash fertilizer were added at planting time while urea was added in split application half at planting and the remains half after 30 - 45 days planting at knee height. The experiment was laid out in randomized complete block design (RCBD) with three replications. The plot size was $18.75 \mathrm{~m}^{2}(3.75 \mathrm{~m} \times 5$ $\mathrm{m}$ ) and consisted of 5 rows. $1 \mathrm{~m}$ distance was left for both between plots and blocks. Spacing of 75 and $15 \mathrm{~cm}$ was used between rows and plants respectively. The tested variety was Misker. All recommended agronomic crop managements were done for all treatments uniformly at their own appropriate time.

\section{Data collection}

The average plant height taking representative ten samples from each plot randomly and measured by tape meter from ground to tip of the head, length of sorghum head, grain yield was collected from central rows, while excluding border rows from each plot separately.

\section{Data analysis}

The data obtained from this research were subjected to analysis of variance using SAS software version 9.0 (SAS, 2003) and treatment effects were compared using the Fisher's Least Significant Differences test at a $5 \%$ significance level.

Table 1. Soil data at planting 


\begin{tabular}{|c|c|c|c|c|c|c|c|c|}
\hline & & & & & Avi.P & Exch.K & & \\
\hline Site & $\mathrm{pH}$ & EC & $\% O C$ & $\% \mathrm{TN}$ & PPM & cmolkg $^{1}$ & $S$ in $P P M$ & Textural class \\
\hline Tiya & 6 & 0.12 & 0.80 & 0.03 & 4.79 & 1.26 & 6.53 & sandy loam \\
\hline Q/Abeba & 6.1 & 0.14 & 0.49 & 0.05 & 23.24 & 0.86 & 7.82 & sandy loam \\
\hline shumsha & 5.8 & 0.14 & 0.49 & 0.04 & 15.68 & 1.35 & 5.34 & sandy clay loam \\
\hline Rubariya & 5.8 & 0.12 & 0.45 & 0.04 & 7.43 & 0.85 & 5.02 & sandy loam \\
\hline Woleh & 5.8 & 0.14 & 0.37 & 0.04 & 7.37 & 0.84 & 6.74 & lomy sand \\
\hline
\end{tabular}

Representative composite soil samples were collected from the surface $(0-20 \mathrm{~cm}$ depth) at planting time from the trial sites, for the analysis of $\mathrm{pH}, \mathrm{EC}, \mathrm{SOC}, \mathrm{TN}$, available P, exchangeable $\mathrm{K}, \mathrm{S}$, and textural class. Each composite sample was made up of ten sub-samples. Finally, the analyzed soil data were interpreted to illustrate the current soil fertility status of each trial site. The chemical properties of soils in the experimental fields were determined using different appropriate analytical procedures of Soil in Sekota Dryland Agricultural Research Center and Tigray soil laboratory.

Soil reaction $(\mathrm{pH})$ was measured from filtered suspension of 1:2.5 soil to water ratio using a glass electrode attached to a digital $\mathrm{pH}$ meter. Soil organic carbon was determined following the wet digestion method as described by Walkley and Black (1934). The percentage of soil organic matter was determined by multiplying soil organic carbon value by 1.724 . Total nitrogen was determined by the micro-Kjeldahl digestion, distillation, and titration method (Sertsu and Bekele, 2000). Available phosphorus was determined following the Olsen method (Watanabe and Olsen, 1965). Exchangeable potassium was extracted by ammonium acetate at pH 7 method (Sertsu and Bekele, 2000). Sulfur is also determined by the Turbidity method and soil texture was determined by the bouyoucos hydrometer method (Bouyoucos, 1962; Beverwijk, 1967).

\section{Result And Discussion}

\section{Soil analysis result at planting}

The soil analysis data was important to identify the level of nutrients in the soil and to determine suitable rates and types of fertilizer for the recommendation. The average soil pH of the trial sites was 5.92, according to Tadesse (1991) it was moderately acidic. Based on the results of soil analysis as shown above in Tablec1, the average total nitrogen (\%TN) ranges from 0.02-0.05, based on Tadesse (1991) it was categorized under very low and low. Besides, the available phosphorus (Av. P) was ranged from 4.7923.24 PPM, based on Cottenie (1980); which grouped under very low, low, medium, and high class. Moreover, soil organic carbon (\%OC) of the trial site was ranging from $0.37-0.8$, as Tadesse (1991), it was very low and low, so improving soil organic amount needs immediate actions through applying 
organic fertilizers sources like organic manure, compost, crop residue retention, and crop rotation (Tulema, 2005; Araya, 2010). Soil textural class was also sandy loam, sandy clay loam, and loamy sand both of them were good for crop production activities but due to its high capacity of infiltration rate, it couldn't store water for a long time in dryland areas. The exchangeable potassium of the trial site ranged from 0.84-1.35, according to FAO, (2006) it is very high and high.

Table 2

Effect of $\mathrm{K}, \mathrm{Zn}$, and B fertilizers on $\mathrm{PH}$ and $\mathrm{HL}$ of sorghum in Sekota district

\begin{tabular}{|lllllllll|}
\hline & Fikreselam & \multicolumn{3}{c}{ Rubariya } & \multicolumn{3}{c|}{ Tiya } & \multicolumn{3}{c|}{ Woleh } \\
\hline Trts. & PH.cm & HL.cm & PH.cm & HL.cm & PH.cm & HL.cm & PH.cm & HL.cm \\
\hline NPS & 157.97 & 18.56 & 164.07 & 18.4 & 134.65 & 17.33 & 147.8 & 21.07 \\
\hline NPSK & 152.17 & 17.88 & 160.07 & 18.46 & 142.05 & 16.81 & 155.48 & 19.87 \\
\hline NPSZnB & 158.22 & 18.24 & 166.17 & 20.4 & 141.2 & 17.46 & 150.4 & 21 \\
\hline NPSZnBK & 149.12 & 18.46 & 156.27 & 17.92 & 138.18 & 17.13 & 158.12 & 19.51 \\
\hline LSD 5\% & NS & NS & NS & NS & NS & NS & NS & NS \\
\hline CV & 2.62 & 2.48 & 3.1 & 4.02 & 2.84 & 1.48 & 7.8 & 5.6 \\
\hline $\begin{array}{l}\text { Where: Trts presents treatment, PH refers plant height, HL stands for head length, NS represents non } \\
\text { significant }\end{array}$
\end{tabular}

Table 3

Effect of $K, Z n$, and B fertilizers on grain yield of sorghum in Sekota district

\begin{tabular}{|lllll|}
\hline & Fikreselam & Rubriya & Tiya & Woleh \\
\hline Trts & GY Kg ha $^{-1}$ & GY Kg ha $^{-1}$ & GY Kg ha $^{-1}$ & GY Kg ha $^{-1}$ \\
\hline NPS & 1480 & 2670 & 1420 & 3230 \\
\hline NPSK & 1370 & 2560 & 1570 & 3070 \\
\hline NPSZnB & 1240 & 2610 & 1460 & 2910 \\
\hline NPSZnBK & 1230 & 2400 & 1450 & 3100 \\
\hline LSD 5\% & NS & NS & NS & Ns \\
\hline CV & 5.87 & 4.5 & 4.01 & 4.8 \\
\hline Where: GY refers to grain yield & & \\
\hline
\end{tabular}


Table 4

Effect of $\mathrm{K}, \mathrm{Zn}$, and $\mathrm{B}$ fertilizers on $\mathrm{PH}$ and the $\mathrm{HL}$ of sorghum in Lasta district.

\begin{tabular}{|lllllllll|}
\hline & \multicolumn{2}{l}{ Genet Mariam } & \multicolumn{2}{l}{ Qechn abeba 1 } & Qechn abeba2 & \multicolumn{2}{l|}{ Shumsha } \\
\hline & PH.cm & HL.cm & PH.cm & HL.cm & PH.cm & HL.cm & PH.cm & HL.cm \\
NPS & $159.39 \mathrm{a}$ & 18.83 & 140.47 & 18.82 & 131.1 & 17.4 & 158.4 & 21.26 \\
NPSK & $146.27 \mathrm{~b}$ & 17.93 & 146.47 & 20.16 & 131.3 & 16.16 & 171.31 & 22.53 \\
NPSZnB & $146.47 \mathrm{~b}$ & 17.33 & 143.27 & 17.36 & 126.36 & 17.4 & 164.91 & 22.26 \\
NPSZnBK & $147.53 \mathrm{~b}$ & 1743 & 145.87 & 18.9 & 132.84 & 17.2 & 149.96 & 18.58 \\
\hline LSD 5\% & 7.4 & NS & NS & NS & NS & NS & 16.05 & NS \\
\hline CV & 6.9 & 3.68 & 2.6 & 4.4 & 2.31 & 2.82 & 2.75 & 9.1 \\
\hline
\end{tabular}

Table 5

Effect of $K, Z n$, and B fertilizers on grain yield of sorghum at Lasta district

\begin{tabular}{|c|c|c|c|c|}
\hline Trts. & Genet Mariyam & Qechn abeba1 & Qechn abeba2 & Shumsha \\
\hline & GY kg ha ${ }^{-1}$ & GY kg ha-1 & $\mathrm{GY} \mathrm{kg} \mathrm{ha}^{-1}$ & $\mathrm{GYkg} \mathrm{ha}^{-1}$ \\
\hline NPS & 1710a & 1080 & 1200 & 3300 \\
\hline NPSK & $1040 b$ & 1240 & 860 & 4010 \\
\hline NPSZnB & $940 \mathrm{~b}$ & 910 & 940 & 2860 \\
\hline NPSZnBK & $1406 a$ & 1140 & 1090 & 3160 \\
\hline LSD 5\% & 0.3 & NS & NS & NS \\
\hline CV & 8.4 & 11.75 & 14.16 & 8.43 \\
\hline
\end{tabular}

\section{Plant Height And Head Length}

Potassium, zinc, and boron fertilizers had no significant effects, among and between treatments on plant height and head length of sorghum in Sekota and Lasta districts at $(p \leq 0.05)$ Table 2 and 4 . Thus the resulting matched with soil analysis results as mentioned in Table 1 . When the available $\mathrm{K}$ in the soil was deficient or not supplied adequately, the growth would be stunted. But the amount of readily available (exchangeable) potassium in the soil to provide the crop was high. This result was in line with (Amare et al., 2018; Hasanuzzaman et al., 2018). Furthermore, zinc and boron have a great role in plant growth and development. However, in the case of these experimental fields, it had no significant effect on plant height and head length. It might be due to the soil full filling the required amount of $Z n$, and $B$ for sorghum. This 
result agreed with (Ayalew and Beyene, 2011; Amare et al., 2018; Kassie et al., 2019; G.Selassie et al., 2020) who reported that $K$ fertilizer application had no significant effect on crop growth parameters of sorghum, maize, wheat, potato and tef in northwestern, southern, and northeastern, Ethiopia. Though, it was contradicted with (Markos et al., 2015; Berhe, 2017; Tesfaye et al., 2021) who reported that $\mathrm{K}$ had a response on maize and wheat agronomic parameters. Similarly, it disagreed with (Pholsen and Somsungnoen, 2004; Bayu et al., 2006) who reported that boron and potassium fertilizers had a significant effect on sorghum height.

\section{Grain yield}

The application of K, Zn, and B fertilizers did not significantly affect grain yield in Sekota and Lasta districts (Tables 3 and 5). The highest grain yield was obtained from the application of NPS fertilizer in most experimental fields. Whereas the lowest yield was recorded from K, Zn, and B combined with NPS. This might be due to the overdose applications of these nutrients. This finding positively correlated with soil analysis data of experimental fields as illustrated above in Table1. Although the overall yield except for Shumsha, Rubariya, and Woleh sites was low due to low soil fertility status and moisture deficit problems. But the yield was equal with (CSA, 2017; Assefa et al., 2020) results. Shumsha and Rubariya sites yield similar to Sebnie and Mengesha (2018) who found 3822 and $2959 \mathrm{~kg} \mathrm{ha}^{-1}$ by using $23 \mathrm{~kg} \mathrm{~N}$ ha ${ }^{-1}$ and $\mathrm{P}_{2} \mathrm{O}_{5}$ for Shumsha, and 46 and $23 \mathrm{~kg} \mathrm{~N} \mathrm{ha}^{-1}$ and $\mathrm{P}_{2} \mathrm{O}_{5}$ for Rubaria. There were yield variations among sites due to soil fertility variation.

$\mathrm{K}, \mathrm{Zn}$, and $\mathrm{B}$ has a role in growth, development, yield increment, diseases resistance, formation of different enzymes for crops (Brady and Weil, 2002), but in the wag-Lasta areas it had no yield advantage on sorghum, rather than the recommended rate of nitrogen and phosphorous fertilizers. This might be due to the soil having enough (high) amount of exchangeable potassium, the current result of this research was agreed to the diagnostic nutrient omission trial result of (SDARC, unpublished; Amare et al., 2010; Amare et al., 2018). Similarly, the current finding in line with Wag-Lasta areas results using $72 \mathrm{~kg}$ $\mathrm{K}_{2} \mathrm{O}, \mathrm{ha}^{-1}$ had no significant effect on teff and wheat yield. Also, this finding is in line with G.selassie et al. (2007), who investigated potato tuber yield had no response for $\mathrm{K}$ fertilizer application in western Amhara Region, Ethiopia. Similarly, it was agreed with (Kassie et al., 2019) who reported that the application of $150 \mathrm{~kg} \mathrm{KCl} \mathrm{ha}^{-1}$ had no yield increment advantage on sorghum, bread wheat, and food barley crops in the north Shewa zone of Amhara region, Ethiopia. Simultaneously, (Ayalew and Beyene, 2011) reported that adding different rate levels of $\mathrm{K}$ fertilizer had no potato tuber yield increment in southern Ethiopia.

The finding of this research contradicted with soil fertility map of the Sekota and Lasta districts. The maps were developed by ATA and the ministry of Agriculture and Natural Resources (2016). It showed more than $98 \%$ of potassium deficiency and more than $80 \%$ NPSZnB deficiency. But, this study proves that $\mathrm{K} Z \mathrm{n}$ and $\mathrm{B}$ nutrients are not a deficit in Wag-Lasta districts, rather they are inadequate amount to provide for crop optimum growth, development, and yield in the areas as shown in table 1 . This study 
result was contrasting with Tilahun et al. (2015), who reported that $\mathrm{Zn}$ is optimal and B below the critical level in Alicho-Woriro, woreda, Siltie zone, Southern Ethiopia. Simultaneously, it was disagreed with (Berhe, 2017; Tesfaye et al., 2021) reported K fertilizer had a yield advantage on wheat in southern, Ethiopia. However, this finding disagreed with (Gebrekorkos et al., 2017; Redai et al., 2018), who reported that NPKSZn, NPK, and NPSZn had yield advantage by melkam variety of sorghum than NP fertilizer in Tigray Region, Ethiopia, and Bekele (2018) who found using $120 \mathrm{~kg} \mathrm{ha}^{-1} \mathrm{~K}_{2} \mathrm{O}$ increases onion yield in Jimma, Southwestern Ethiopia. Similarly, (Anjum, 2017; Nadim et al., 2012), examined that Foliar application of $1 \% \mathrm{Zn}$ and $0.5 \% \mathrm{~B}$ had to pronounce results on maize yield and boron $2 \mathrm{~kg} \mathrm{ha}^{-1}$ recorded more grains spike ${ }^{-1}$, higher grain weight, and increased grain yield of wheat.

\section{Conclusion And Recommendations}

Application of $\mathrm{K} \mathrm{Zn}$ and $\mathrm{B}$ fertilizers had an insignificant effect on plant height, head length, and grain yield of sorghum, in Sekota and Lasta districts. In most trial sites yields obtained from NPS fertilizer are better than NPSK NPSZnB and NPSZnBK, as a result, these fertilizers had no yield advantage in the districts because the districts' soil has a sufficient amount of exchangeable potassium for optimum crop production. Soil fertility maps of Sekota and Lasta district are unrelated to the current soil status of potassium zinc and boron nutrient content. Currently to increase production and productivity of sorghum in Wag-Lasta areas using of recommended rate of nitrogen and phosphorous with organic fertilizer sources for each district is the best option rather than using $\mathrm{K} \mathrm{Zn}$ and $\mathrm{B}$ fertilizers, and the effect of $\mathrm{K} \mathrm{Zn}$ $\mathrm{Cu} B$ and other essential nutrients should be checked as they will be expected deficit from the soil in the long run.

\section{Declarations}

\section{Acknowledgment}

Researchers of this experiment express their deepest gratitude to the Amhara Agricultural Research Institute for funding the research work, and Sekota Dryland Agricultural Research Center for facilitating logistics during the research work.

Authors' contributions: Tilahun Esubalew and Workat Sebnie conceptualized and collected the necessary data of this study, Tilahun Esubalew analyzed, interpreted the data, and wrote the manuscript. Both authors read and approved the final manuscript.

Funding: This study received no external funding.

Data availability statement: Data included in the article.

Ethics approval and consent to participate: Not applicable.

Consent for publication: Not applicable. 
Competing interests: The authors declare no competing interests

\section{References}

1. Abay A, Sheleme B (2011) The influence of potassium fertilizer on the production of potato (Solanum tuberosum L.) at Kembata in southern Ethiopia. J Biol Agri Healthcare, 1(1), 1-13

2. Abebe A, Aemiro B, Getaway G, Tesfaye A, Alemu L (2020) Evaluation of sorghum (Sorghum bicolor (L.) Moench) variety performance in the lowlands area of wag- Lasta, northeastern Ethiopia. Cogent Food and Agriculture (2020), 6: 1778603

3. Admassu M, Wassie H, Walelign W (2015) Response of maize (zea mays L.) to potassium fertilizer at Hadero, southern Ethiopia. DOI:10.13140/RG.2.1.2915.9443

4. Amelework BA, Shimelis HA, Laing MD, Ayele DG, Tongoona P, Mengistu F (2016) Sorghum production systems and constraints, and coping strategies under drought-prone agro-ecologies of Ethiopia. South African Journal of Plant and Soil. 33(3):207-17

5. Anjum SA, Saleem MF, Shahid M, Shakoor A, Safeer M, Khan I, Farooq A, Ali I, Nazir U (2017) Dynamics of soil and foliar-applied boron and zinc to improve maize productivity and profitability. Pakistan Journal of Agricultural Research, 30(3): 294302.DOI http://dx.doi.org/10.17582/journal.pjar/2017.30.3.294.302

6. Balew T (2005). Integrated plant nutrient management in crop production in the central Ethiopian highlands (Doctoral dissertation, Norwegian University of Life Sciences)

7. Baye TG (2017) Poverty, peasantry and agriculture in Ethiopia. Annals of Agrarian Science. 15(3):420-30

8. Bayu W, Rethman NF, Hammes PS, Alemu G (2006) Effects of farmyard manure and inorganic fertilizers on sorghum growth, yield, and nitrogen use in a semi-arid area of Ethiopia. Journal of plant nutrition. 29 (2):391-407

9. Beverwijk A (1967) Particle size analysis of soils by means of the hydrometer method. Sedimentary Geology, 1, 403-406

10. Bouyoucos GJ (1962) Hydrometer method improved for making particle size analyses of soils 1. Agronomy Journal, 54 (5), 464-465

11. Brady NC, Weil RR (2002) The Nature and Properties of Soils. Thirteenth Edition.

Pearson Education Asia. Delhi, India. 960P

12. Cottenie A (1980) Soil and plant testing as a basis of fertilizer recommendations. FAO Soil Bulletin 38/2. Food and Agriculture Organization of the United Nations, Rome, Italy

13. Central Statistical Agency (2017) Report on area and production of crops. Statistical Bulletin 578. Addis Ababa, Ethiopia

14. Eyob T, Kebebew k, Tekalign M, Hailu S (2015) Assessment and Mapping of some soil Micronutrient status in the agricultural Land of Alicho-Woriro woreda, Siltie zone, Southern Ethiopia 
15. FAO (Food and Agriculture Organization) (2006) Plant nutrition for food security: A guide for integrated nutrient management. FAO, Fertilizer, and Plant Nutrition Bulletin 16, Rome, Italy

16. Gebremedhin B (2017) Response of potassium fertilizer on bread wheat (Triticum aestivum L.) in acidic soil of Tsegede highland, northern Ethiopia

17. Gebremeske G, Yemane G, Solomon Hailu (2017) Response of Sorghum (Sorghum bicolor (L.) Moench) varieties to blended fertilizer on yield, yield component, and nutritional content under irrigation in Raya Valley, Northern Ethiopia. Inter J Agri Biosci, 6(3): 153-162

18. Hagos B, Tekalign M, Kassa T (2017) Potassium Fertilization and its Level on Wheat (Triticum aestivum) Yield in Shallow Depth Soils of Northern Ethiopia. J. Fertil Pestic 8: 182. doi:10.4172/2471-2728.1000182

19. Hailu A (2010) The effect of compost on soil fertility enhancement and yield increment under smallholder farming: a case of Tahtai Maichew District-Tigray Region, Ethiopia. Inst. für Bodenkunde und Standortslehre

20. Kenzemed K, Beza S, Getachew L, Lisanu G, Genet T (2019) On-farm Verification of Potassium Fertilization for Major Cereal Crops under Balanced Fertilizers in North Shew Zone of Amhara Region, Ethiopia

21. Ministry of Agriculture and Natural Resources and Agricultural Transformation Agency of Ethiopia (2016) Soil Fertility Status and Fertilizer Recommendation Atlas of Amhara National Regional State, Ethiopia: 297 pages

22. Hasanuzzaman M, Bhuyan MHM, Nahar K, Hossain M, Mahmud JA, Hossen M, Fujita M (2018) Potassium: a vital regulator of plant responses and tolerance to abiotic stresses. Agronomy, 8(3), 31

23. Muluneh B (2018) Effects of different levels of potassium fertilization on yield, quality and storage life of onion (Allium cepa L.) at Jimma, Southwestern Ethiopia. J Food Sci Nutr. 2018; 1(2):32-9

24. Murphy HF (1968) A report on fertility status and other data on some soils of Ethiopia. Collage of Agriculture HSIU. Experimental Station Bulletin No. 44, College of Agriculture, Alemaya, Ethiopia: $551 \mathrm{p}$

25. Nadim MA, Awan IU, Baloch MS, Khan EA, Naveed K, Khan MA (2012) Response of wheat (Triticum aestivum L.) to different micronutrients and their application methods. J. Anim. Plant Sci, 22(1), pp. 113-119

26. Onyango RM, Mwangi TK, Kiya WW, Kamidi MK (1998) Maintaining soil productivity by combining organic and inorganic fertilizers in smallholder farms within the Kitale Region in Kenya. Proceedings of the 6 the Eastern and Southern Africa Regional Maize Conference. 21 st $-25^{\text {th }}$ Sept 1998. pp. 242246

27. Pholsen S, Somsungnoen N (2004) Effects of nitrogen and potassium rates and planting distances on growth, yield and fodder quality of a forage sorghum (Sorghum bicolor L. Moench). Pak. J. Biol. Sci. 7 (10):1793-800

28. Sahlemedhin S, Taye B (2000) Procedures for soil and plant analysis: Technical P. 74. National Soil Research Center

Page $11 / 14$ 
29. Redai W, Tesfay A, Yemane G (2018) Effect of NPK and blended fertilizer application on Yield, Yield Component and its profitability of Sorghum (Sorghum bicolor (L.) Moench) varieties under rainfed conditions in north-western Tigray, Ethiopia

30. Tadele A, Zerfu B, Erkihun A, Asmare W, Birhanu A, Mengistu M, Tesfaye F, Desalew F (2018) Crop response to balance nutrient application in northwestern Ethiopia. Blue Nile journal of agricultural research (1), pp1-14

31. Tadele A, Tesfaye F, Yihenew G (2010) Response of maize, malt barley, and tomato to potassium. In; Birru Yitaferu, Teshome Tessema, Zewdu Ayalew (eds.). Proceedings of the Third Annual Regional Conference on Completed Research activities on soil and water management, Forestry and Agricultural Mechanization 1-4 September 2008, Amhara regional agricultural research institute ARARI, Bahir Dar, Ethiopia, pp 67-75

32. Tekalign T (1991) Soil, plant, water, fertilizer, animal manure and compost analysis.

33. Working Document No. 13. International Livestock Research Center for Africa, Addis

34. Ababa, Ethiopia

35. Tigist T, Fanuel L, Abera $H$ (2021) Response of Bread Wheat (Triticum aestivum L.) to Potassium (K) and Blended NPS Fertilizer Rates in the Nitisols of Southern Ethiopia. Applied and Environmental Soil Science, 2021

36. Walkley A, Black IA (1934) An examination of the Degtjareff method for determining soil organic matter, and a proposed modification of the chromic acid titration method. Soil science. Jan 1;37(1):29-38

37. Watanabe FS, Olsen SR (1965) Test of an ascorbic acid method for determining phosphorus in water and $\mathrm{NaHCO} 3$ extracts from soil. Soil Science Society of America Journal. 29 (6):677-8

38. Workat S, Merssie M (2018) Response of nitrogen and phosphorus fertilizer rate for sorghum (Sorghum bicolor L. Moench) production in Wag-Lasta area of Ethiopia

39. Yihenew G, Tesfaye F, Tadele A (2007) Soil K status and K requirement of potato growing on different soils of western Amhara, Proceedings of the $2^{\text {nd }}$ annual regional conference on completed natural resources management research activities (18-19 September 2007)

40. Yihenew G, Eyayu M, Dinku M, Fentanesh M, Demelash D (2020) Response of crops to fertilizer application in volcanic soils. Heliyon, 6(12), e05629

\section{Figures}




\section{Recommended Fertilizers for Sekota Woreda}

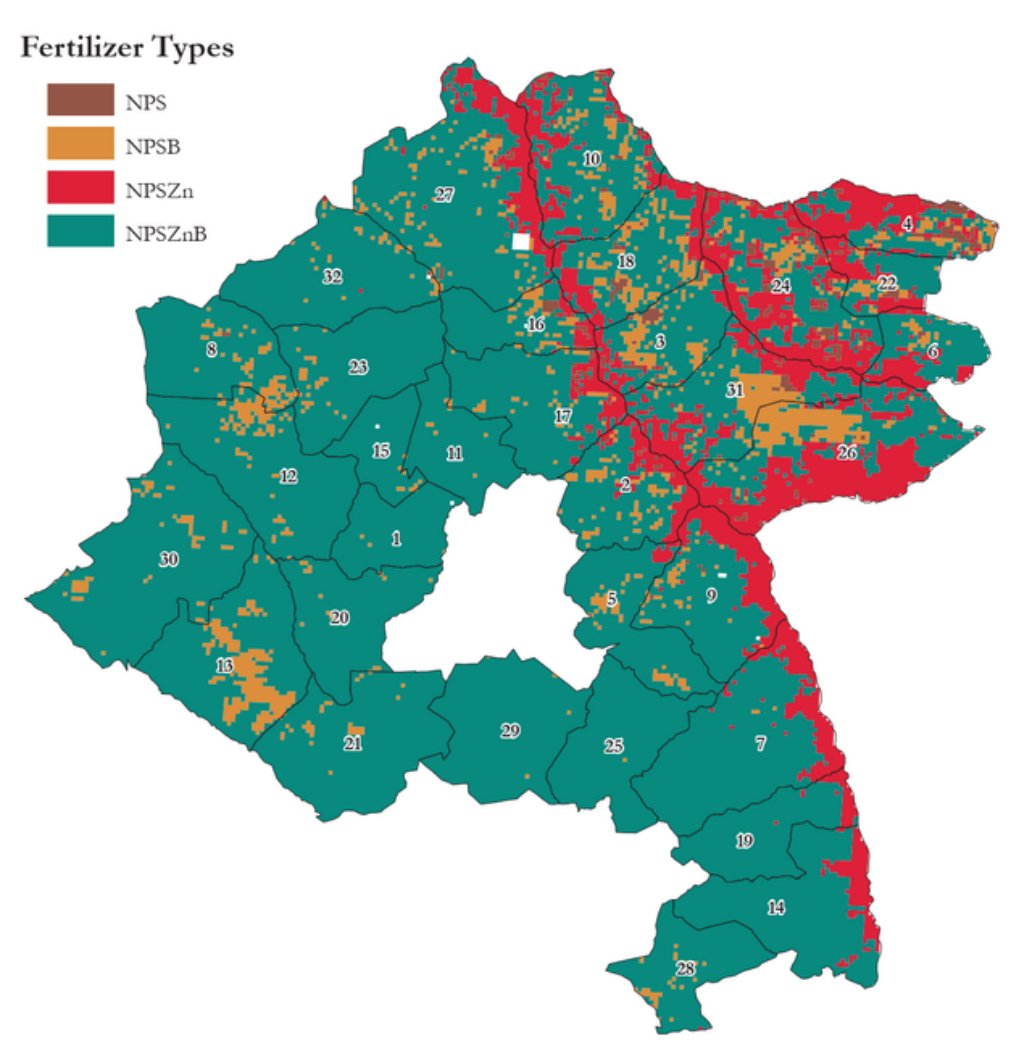

ID Kebele Name ID Kebele Name ID Kebele Name ID Kebele Name

1 Addis Alem 9 Edeget Chora 17 Melake Genet 25 Tiya Kidane Meheret

2 Akime 10 Etekinu

3 Arisheriwa 11 Fekere Selam

18 Mikun 26 Tsata

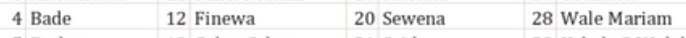

5 Berbere 13 Gebre Selam 21 Saida 29 Kebele 2 Woleh

6 Chireye 14 Hamusit 22 Selamegie 30 Yehun Abeba

7 Dabila 15 Mahebere Genet 23 Seriyal 31 Zenziba

8 Debre Berihan 16 Mehebere Selasie 24 Shemila Alebata 32 Zuna Chirkose

Legend

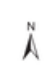

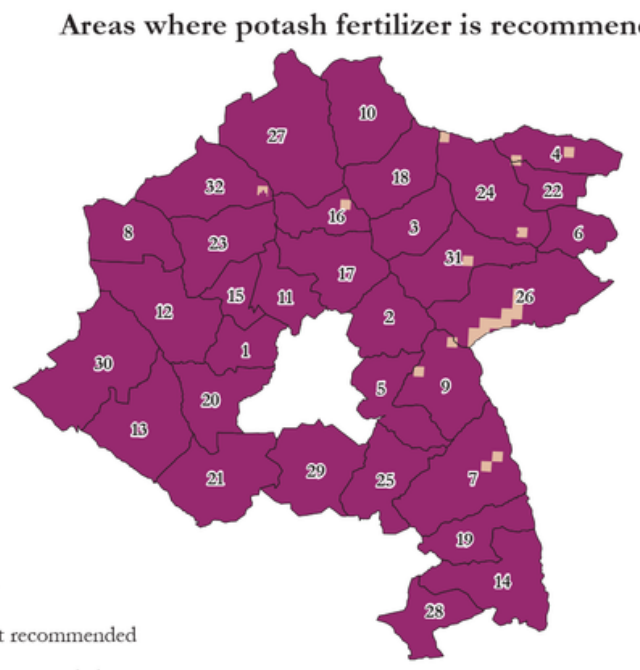

Recommended

\section{Figure 1}

Soil fertility map of Sekota district developed by ATA 


\section{Recommended Fertilizers for Lasta Woreda}

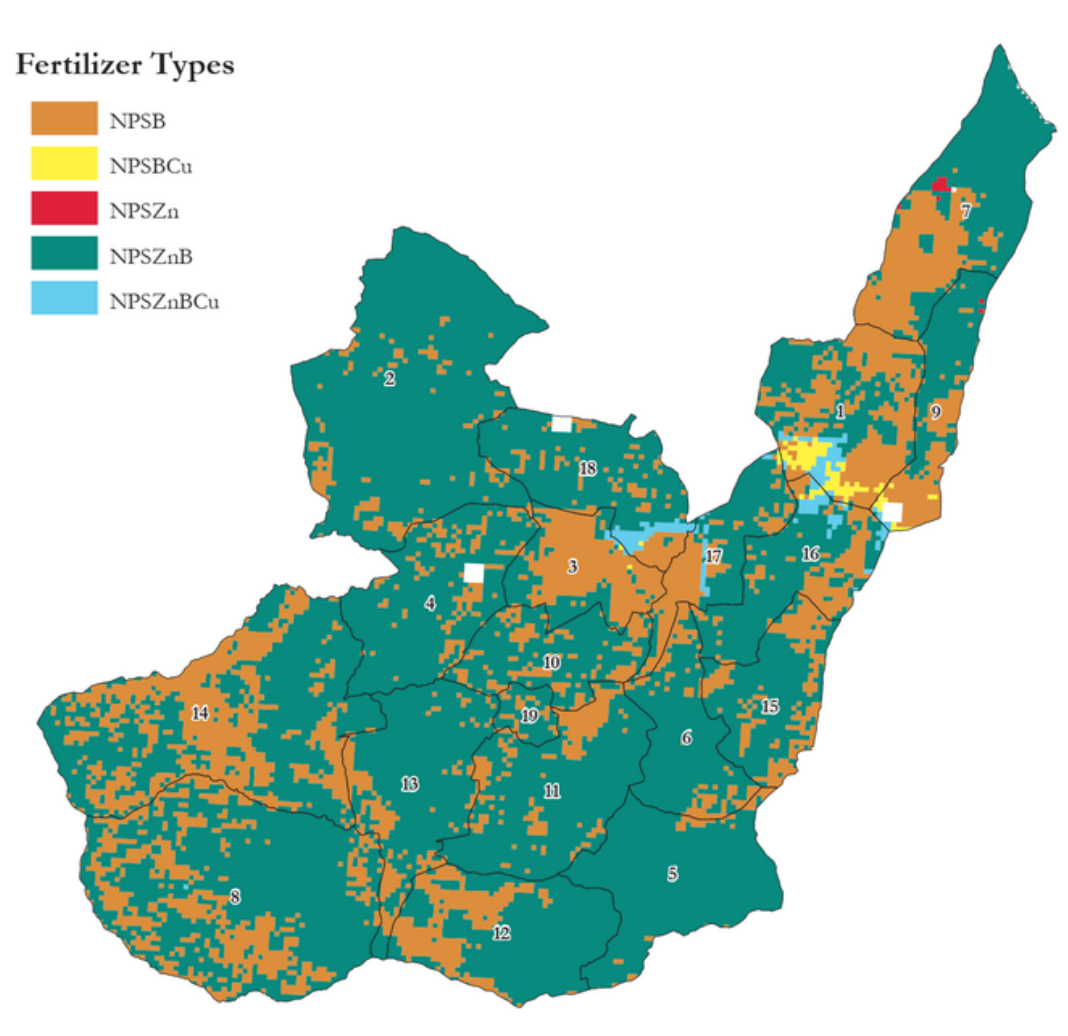

$\hat{\Lambda}$

Legend

ID Kebele Name

1 Abune Yosefe

2 Bilbela

3 Degosach

4 Debre Loza

5 Genete Mariyam

6 Getere Medana Ameba Tsion

7 Grareya

8 Geleset

9 Anejefate

10 Medage
ID Kebele Name

11 Nakuto Le Ab

12 Shalo Giyorgis

13 Shumisheha

14 Sorba

15 Tadiyos Amiba

16 Telfetit

17 Wedebea

18 Yimrah

19 Lalibela Town

Areas where potash fertilizer is recommended

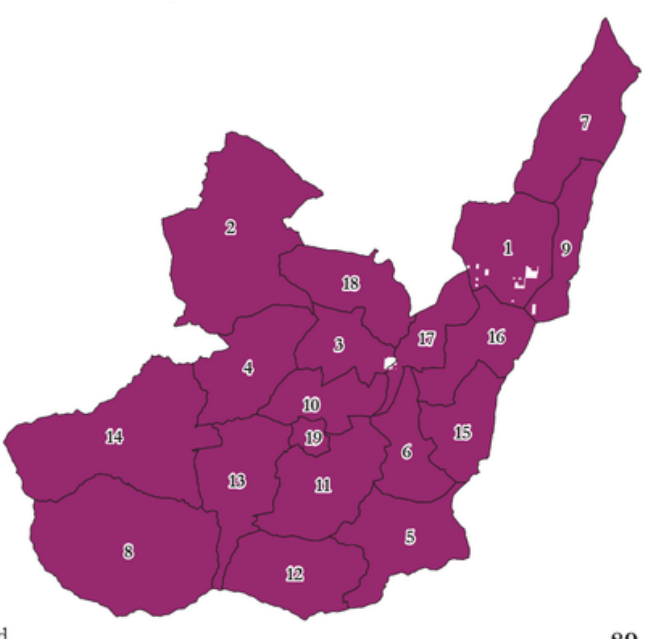

89

\section{Figure 2}

Soil fertility map of Lasta district developed by ATA. 